\begin{tabular}{|c|}
\hline Journal of Political Science \\
(A Peer-Reviewed, Open Access International Journal) \\
ISSN 2362-1273 (Print); ISSN 2773-8132 (Online) \\
Volume 21, February 2021, pp. 19-30 \\
https//: www.ejournal of pncampus.edu.np/journals/ips/ \\
\hline
\end{tabular}

\title{
Good Governance in Nepal: Legal Provisions and Judicial Praxis
}

\author{
Bimal Prasad Lamichhane \\ Advocate, Supreme Court of Nepal
}

Corresponding Author: Bimal Prasad Lamichhane, Email: lcbimalprasad@gmail.com

DOI: https://doi.org/10.3126/jps.v21i0.35260

Received 24 December, 2020, Reviewed 19 January 2021, Published 1 February 2021

\begin{abstract}
Good governance is about fair application of authority and utilization of resources in implementing coherent governing plan for the best interests and priorities of the people at large. It aims at protection and promotion of rights, welfare and well-being of the citizens through legitimized democratic governance under rule of law. It is avenues for peace, crime control, fairness of public decision with legal certainty and equality. It avails bridled governmental power, qualified administration, and a system of fraud and corruption-free state operation. In Nepali context, The Constitution of Nepal 2015, Commission for the Investigation of Abuse of Authority Act 1991, The Prevention of Corruption Act 2002, Public Procurement Act 2007 and Rules 2008, Good Governance Act 2008, Right to Information Act 2007 and Rules 2009, Local Government Operation Act 2017etc. are the primarily statutory measures to ensure good governance in Nepal. But the legal provisions and practice is not sufficient for ensuring good governance in Nepal. Some remarks on the application of these laws to an end of good governance have been overviewed by apex court in this relation. This article explores the concept as well as elements of good governance and descriptively analyzes various laws, case laws and principles developed by the Supreme Court of Nepal in the issue of good governance. This paper also aims at assessing the strengths and weaknesses of these laws and judicial practices from the internationally accepted good governance norms and principles.
\end{abstract}

Keywords: Court, democratic, good governance, governance, law, process, transparent

\section{Introduction}

The concept of governance is as old as human civilization and the society/state itself. Human beings do not exist independently and in isolation. A person who lives outside the society and in isolation is either god or a beast. In the ancient time, human beings began to unite and associate themselves in some sort of groups such as family, society, community and state. The family as the smallest association of people forms the society, the group of 


\section{Good Governance in Nepal: Legal Provisions and Judicial Praxis}

society and the community forms the state and finally the group of state leads to the world community. Being genus, rational and social animal, human beings live in a society and they are co-existent, interrelated and interdependent with each other. Cordial relations and understanding among people is indispensable for the smooth continuation of society. If a group or society is to continue smoothly, some form of social order is necessary. To regulate human activities, relations, protection, interactions properly some sort of governance and governance mechanisms is required. Therefore, the society to function, the social systems, social relationships and social order within the society people started to develop and follow social rules, social norms and values, religion, culture, custom, usages, rituals, societal standards and practices or mores to function as governing institutions. All these social rules and practices are required to regulate and govern the human activities and society. In the modern society, there are several rules, regulations and laws to have governance in national level, regional and international arena.

The notion of good governance itself was originated in the practice of international donor agencies, particularly of the World Bank, not in any academic discourse or context. It was used for the first time in the 1989 World Bank Report on Sub-Saharan Africa, which characterized the crisis in the region as a 'crisis of governance' including rampant corruption and resistance to reforms by recipient governments, rendering the provision of aid ineffective (Weiss \& Steiner, 2007, p.1545). In the end of eighties when the World Bank and the International Monetary Fund stated that the growth and equitable development of many developing countries was frustrated by the poorly functioning public sector institutions and weak governments the idea of good governance was developed globally (Addink, 2019, p.263).The United Nation is especially involved in the development aid policy and the IMF and World Bank are the leading international institutions in relation to countries financial policy(Addink, 2019, p. 48). Later other institutions such as World Trade Organization, Organization for Economic Cooperation and Development (OECD), European Union etc. were quite active in this field and playing a positive role in promoting and institutionalizing the concept of good governance. Good governance has become the major buzzword in aid policy and development thinking today. To lending countries, good governance is first of all yet another element of conditionality for indispensable loans, and ultimately for their acceptance as equal participants in the global economy. It coincided as well with the international compliance of the left with the position that free markets are the primary tool for the development of what were once known as the Second and Third Worlds. Particularly the theme of good governance is developed for the under-developed, developing and third world countries to make progress and achieve stability.

Governance and good governance are the vocabularies which are mostly used in the literature of law (Jurisprudence, International law, Constitutional law, Administrative law, Corporate law etc.), sociology, management, economics, political science, administrative sciences, international relation, development studies and public administration. The terms like governance and good governance are commonly used terminologies in the examination of the way government is run. Etymologically, the term good governance is composed of two words i.e. 'good' and 'governance'. Literally, 'good' indicates sound, reliable, effectual, valid or under the law and 'governance' signifies the exercise of power to manage the public affairs. Thus, good governance means delivering high-quality programs and services in an accountable, responsive and lawful manner. 'This concept has become a universally recognized phenomenon. Good governance is about utilizing power and resources in a way that maximizes the welfare of the people. It is closely associated with the control and rule of 


\section{Good Governance in Nepal: Legal Provisions and Judicial Praxis}

administration of a state through implementation of laws' (Aryal, 2011, p. 30) in a fair and legitimate manner.

Good governance is the system which is conscious oriented and participatory, following the rule of law that is effective and efficient, accountable, transparent, responsive, equitable and inclusive. Governance has been usually qualified by the word 'good' to describe its features about the arrangement and exercise of authority made in the interests of the society/state and the contents of programs devoted to directly benefit the people within it, as also the degree of accountability, transparency and participation permitted to control its various processes (Rijal, 2011, p. 19). The term good governance is closely associated with control, rule or administration of the state through implementation of laws (Dahal, 1999, p. 68). Democracy is an essential prerequisite of good governance. A democratic government may also face crisis of governability. However, a democrat system is essential because that alone can promote the ethics of economic and political freedom and development for individuals to increase the mass participation, which are features of good governance. The good governance is a situation where there is a mutual trust between the state and the citizen (Ali, 2020, p. 70) and their interaction and interrelation.

Participatory democracy is the foundation of good governance. All the citizens of democracy are happy, prosperous, healthy, intelligent, peace and justice lover (Dahl, 2005, p.61). Governance which is participatory in political sense angle, productive in economic angle, stable in biological angle, lively in cultural perspective, justifiable in social viewpoint is good governance (Bhattarai, 2013, p. 28). Therefore, good governance covers political, economic, biological, cultural and social subjects of the society. Basing on the above introductory preview some questions arises: what things do the good governance have so that it is so popular and important to all? Has Nepal incorporated the principle of good governance in the legislations? This article intended to elucidate on these research questions along with the framed objectives of this study.

\section{Objectives and Methodology}

Basically, this paper is a theoretical and normative work. The general objective of this article is to clarify the notion of good governance and its fundamental attributes. The specific objective of this academic writing is to explore and analyze major Nepali legal provisions, judicial praxis and its efficacy in the application of good governance in Nepal as well as clarify the significance of legal and constitutional provisions of good governance in democracy. In this paper the author has used qualitative, doctrinal and descriptive research methodology and content analysis is the main tool of this research. There are several aspects and issues of good governance but this article is limited to analyze on the Nepali statutory provisions and judicial response regarding good governance. With the help of sufficient literature, reports, laws and case laws. The paper has been prepared to justify the fact that good governance is possible if its features are available. Data and information have been collected from secondary sources/documents. The Constitution and other laws, published research works, authorized books, journals articles, legal research data base such as Hein Online, jstor and various websites are retrieved from both print and online sources. After collecting the data, they are descriptively analyzed and analytically explained.

\section{Results and Discussion}

Good governance is a process and system of governance where there is end of impunity, corruption, evil governance, mis-governance and mal-governance. According to Nanda 


\section{Good Governance in Nepal: Legal Provisions and Judicial Praxis}

(2006), 'The rationale is that with good governance that is, combating corruption, nepotism, favoritism, bureaucracy and mismanagement and transparency, accountability, and proper procedures, aid would be effectively used to achieve the objective of reducing poverty' (p. 272). Hence, good governance is the reformed concept of bad, autocratic, undemocratic, bad and poor governance. The term good governance denotes the governance process in which accountability, transparency and participation are engineered to make the conduct of governance democratic, people-oriented and participatory (Rajbhandary, 2002, p. 4). It is considered as the last resort whereas the governance reform is a journey for reaching the desired destination (Bhattari, 2013, p. 29). It leads to good management, good performance, good stewardship of public money, good public engagement and ultimately good outcomes (Bhatta, 2076, p. 384) and people’s satisfaction.

Good governance is the foundational principles which set forth how changes in the governmental structure can be effectuated. It provides parameters for the exercise of power in a lawful and democratic way and lay out the citizen's basic rights. It is about the quality of the governance by those institutions which act in the public interest (Addink, 2019, p. 187).Pai Panandiker sees, "good governance as it pertains to a nation state which handles its people to lead a peaceful, orderly, reasonable, prosperous, participatory lives" (Barthwal, 2003, p.287).According to Michael Johnston, "good governance is a competent management of a country's resources and affairs in a manner that is open, transparent, accountable, equitable and responsive to people's needs” (Ali, 2020, p.67). It basically attempts to establish a quality relationship between the rulers and the ruled (Ali, 2020, p.68). In it, the interest of people is primordial. As Karpen (2010) views, 'For this government and administrative agencies must be efficient, simple, speedy, must provide for integrity of the source and trust for the consumers or citizens' (p. 19).Good governance, people centered governance, responsive governance all call for a collective sense of destiny and direction for human beings (Singh, Ansari \& Singh, 2009, p. 1110). Equality, greater participation, welfare and pursuit of happiness of citizens, transparent, effective, accountable and citizen's friendly government would help in enhancing and promoting good governance. Therefore, the interest of people must be served and recognized by various ways in good governance.

The shift that has occurred from the notion of governance to that of good governance implies an additional normative dimension pertaining to the quality of governance. A system of good governance, consequently, stems from the fulfillment of particular process requirements, both with respect to decision making and to the formulation of public policy (Weiss \& Steiner, 2007, p. 1548).According to Gavriluta \& Lotos (2018), "good governance represents, the effective management of public affairs by generating a set of rule, in order to promote and strengthen the values of the society searched by individuals and groups" (p. 124). There are several attributes or elements of good governance which was developed by various researchers and institutions. Among them the eight elements of good governance developed by UNDP, 1989 are the foundational elements or facets which paves the way of good governance worldwide; they are 'conscious oriented; participatory, follows the rule of law, effective and efficient, accountable, transparent, responsive, equitable and inclusive' (Dhaka, 2010, p. 4). These eight elements have developed into universal elements of good governance, although other norms or differing terminology might be found in practice as well, but these are accepted across cultures or are applicable across the board. These eight basic elements of good governance have been found to be the hard core of the concept of good governance and became indicators or measures to test the legitimacy of the good governance internationally. These principles have become key in a tentative list of good 


\section{Good Governance in Nepal: Legal Provisions and Judicial Praxis}

governance requirements which have later been described by the World Bank, the IMF, and the WTO (Addink, 2019, p. 263), OECD etc.

The concept of good governance conveys the qualitative dimension of governance that indicates effective, efficient, participative, or democratic form of government which is responsible for transparent and accountable management of human, natural, economic and financial resources for equitable and sustainable development (Rahman, 2016, p. 40).It refers to the ability to deliver goods to the stakeholders which also refers to the elimination of mal governance and the establishment of good governance through democratic processes and rule of law so that citizens of a country and members of a society do not suffer. It aims to make the various agents of a political system work for the welfare, betterment and common good of all the citizens, especially of the marginalized and the vulnerable communities (Singh, Ansari \& Singh, 2009, p. 1110).It is a dynamic concept. It encompasses fast changing political, social and economic milieu along with the international environment and conditions of operational governance. Good governance is associated with efficient and effective administration in a democratic framework an administration considered to be citizen friendly, citizen-caring, responsive and respecting human rights at large (Singh, Ansari \& Singh, 2009, p. 1109).

Good governance requires that state, private actions or other actors of governance must obey the law: separation of powers, monitoring, and guaranteed access to the judiciary for every citizen (Karpen, 2010, p.17).Government, judiciary and administration are bound by the constitution, law and basic principles of justice (Karpen, 2010, p. 23). The norm of good governance is both a rule for the administration, public entities as well as for protecting the citizens, safeguarding their rights and ensuring the common good of all (Addink, 2019, p. 187). It refers to certain standards that institutions and officials must abide (Addink, 2019, p. 66).Good governance characterizes a government which is democratic, open, accountable and transparent, and which respects and fosters human rights and the rule of law(Riley, 2007, p.1058). It is an essential first step in strengthening rule of law, constitutionalism, government stability, exercising greater political sovereignty, and enhancing prospects for increased political and economic development (Riley, 2007, p. 1082).Good governance is a regime to govern the legitimacy of the system and rule of law, pluralism and democracy, the human rights, inclusiveness, transparency, accountability. All these elements and regime provides a ground for legitimate functioning of good governance.

Justice is at the heart of good governance. As Ali (2020) states, 'Therefore, it values justice as most important for establishing a just society in which people from all walks of life, from different faiths can live in peace and harmony with no discrimination' (p. 71).The good governance encompasses interaction among structures, processes and traditions that determine how power is exercised, how decisions are taken and how citizens and stakeholders have their say secured (Sangroula, 2020, p. 1).Good governance is legitimate, accountable and effective ways of obtaining and using public power and resources in the pursuit of widely-accepted social goals (Ali, 2020, p. 65). Therefore, good governance standards are skeleton to continue and flourish the state and it is also citizen friendly governance system. It is often said that good governance is a typical western or more specifically, European concept (Addink, 2019, p. 210).Within western democracy, governance is understood either as a management function or as a leadership role played by the government, politicians, business, academics, not for profit and community organizations or just particular individuals within civil society (Marinova et. al., 2015, p. 


\section{Good Governance in Nepal: Legal Provisions and Judicial Praxis}

47). Good governance is also new trend and area of study of modern development in jurisprudence.

Various scholars and jurists have expressed their ideas and views on the good governance. Jurisprudentially, the term 'state' and 'good governance' were considered to be synonymous as it is found in the writings of Hobbies, Locke, Rousseau, Mill, and Marx. They believed that coercive power was given to the state by men, with the hope of realizing good governance through their writings. They have advocated different forms of political and administrative systems where the interest of the citizens reconciles with the role of state and its method of governance and good governance (Ali, 2006, p. 375). The concept of protecting life, liberty and property of an individual by John Locke, protecting life, liberty and pursuit of happiness by Thomas Pine, maintaining social harmony and the concept of ideal state by Plato, distributive and corrective justice of Aristotle, protecting individual freedom of Kant, 'respect and participation of all with harmony by Stammler' (Galligan, 2007, p. 2), achieving the greatest happiness of the greatest number of people by Bentham, non-violence of Mahatma Gandhi, etc. are related to the idea of good governance.

In the eastern philosophy, 'good governance was termed as Adarsa Rajya or Ram Rajya in the eastern philosophy whereas it was named as Ideal State in the western philosophy. At the time of Ram, did not provide the decision without making detailed discussion among the people. Thus, Ram Rajya specifies ideal state similar to the Platonic concept of ideal state' (Dahal, 2007, p. 1).Eastern philosophy is based on and guided by the religious and Vedic norms and values. Thus, the eastern philosophy and society is influenced by the Vedic culture of Ram Rajya as well as new term good governance (Dahal, 2017, p.30). Additionally, the Vedic ideals evolved millenniums ago reads as "sarve bhabantu sukhina: sarve santu niramaya: sarve bhadrani pasyantu: makaschit dukhabhagana" meaning let all the people of the world live peace and happiness; let them keep free from all form of sorrow and misery (Khanal, 2018, p. 122). Those provisions reveal to ensure good governance to maintain humanity and to protect human values and dignity in favorable environment.

Kautilya has also highlighted the need of good administration to look after the welfare of the people. Kautilya's Arthashastra is the art of government and administration, the duties of king's ministers, officials, the art of diplomacy etc. The basic indicator of good governance is that the ruler must surrender his interest before the common interest of the people. A king is expected to behave in a most righteous manner. The happiness of the king lies in the happiness of the people and the good of the people alone makes the good of the king. In the happiness of his subjects lies his happiness; in their welfare his welfare, whatever pleases him he shall not consider as good, but whatever makes his subject happy, he shall consider good. Therefore, the good (about governance) is not one which pleases the king but one which pleases the people. According to Prithvi Narayan Shahin his Dibya Upadesh, the king should oversee the justice system and not let injustice take place in the kingdom. For Rijal (2011), 'This saying signifies good governance. Even earlier scriptures like Balmiki Ramayan, Mahabharat and Sukra Niti lay a similar stress on governance and good governance.' (p. 268). The concept of welfare state of modern time is also the related to the idea of good governance.

The performance and measurement of democracy no longer stand differently from good governance. The connection between both concepts and in short, success in the practice of democracy lies strongly in the understanding that democracy, understood as good 


\section{Good Governance in Nepal: Legal Provisions and Judicial Praxis}

governance carries with it the capacity for improving society and welfare of its citizens' (Gilbert \& Allen, 2014, p. 526). Democracy follows the rule of law and the rule of law is the most essential element of good governance. Also, legitimacy if the government is another element of good governance and the most important factor of democracy (Dahal, 2017, p. 29). Therefore, legal and constitutional provisions of good governance is essential in democracy.

Federal democratic republic of Nepal has been institutionalized through the promulgation of Constitution of Nepal 2015. The new constitution theoretically supports the theory of good governance in Nepal (Dahal, 2017, p. 29). The norms and values of good governance are specified in the Constitution, legislations, plan and policy documents, and directives of legislature, judiciary and constitutional bodies. The preamble of the Constitution of Nepal 2015 assumes good governance as one of key constituent of the legal and political system of Nepal. The Constitution of Nepal envisions the rule of law and a welfare state based on open society where citizens enjoy the right to information and maximum participation of the people in governance through the medium of decentralization. The Nepali Constitution incorporated the supremacy of constitution in Article 1 by mentioning constitution as the fundamental law of Nepal. Article 5 make commitment for safeguarding freedom, the rights of the Nepalese people, economic wellbeing and prosperity as a national interest of Nepal. Part-3, Article 16-46 is related about the fundamental rights of the Nepali people. All the fundamental rights and its remedy ensure citizens to live dignified life and these rights cannot be entertained by the citizens in the absence of good governance.

Similarly, Part-4 of the Constitution is about the Directive Principles, Policies and Obligations of the State where there are several policies of the state for maintaining good governance in Nepal. Directive principles as a policy 'guidelines of the state are kept in the constitution for the governance of the state' (The Constitution of Nepal, 2015, Article 49), proper functioning and achieving the multiple goals of the state. It is used by the state as a fundamental tool to ensure good governance. The Constitution of Nepal, 2015 is based on the democratic norms and values including the people's competitive multiparty democratic system of governance, inclusive and participatory democracy, civil liberties, fundamental rights, human rights, adult franchise, secularism, periodic elections, full freedom of press, independent, impartial and competent judiciary, separation of power and check and balance, rule of law, freedom of opinion and expression, freedom of press, equality, justice, right to information, social justice and build a prosperous nation etc. incorporated in the constitution are the facets or attributes of good governance. The constitutional bodies such as National Human Rights Commission, Commission for the Investigation of Abuse of Authority, Public Service Commission, Election Commission, National Natural Resources and Fiscal Commission and other commissions provisioned by the Constitution are working for safeguarding the norms of constitution, protecting the rights of citizens and ensuring good governance.

Good Governance (Management and Operation) Act 2008 is the specific statutory provision for the good governance. This Act is enacted 'to make legal provision in relation to good governance by making public administration of the country pro-people, accountable, transparent, inclusive and participatory and make available its outcome to the general public; upon adopting the basic values of good governance like rule of law, corruption-free and smart (lean or smooth) administration, financial discipline, and efficient management of public work and resources to create situation for providing public services in speedy and 


\section{Good Governance in Nepal: Legal Provisions and Judicial Praxis}

cost-effective manner; by bringing into execution (enforcement) of the right of the citizens upon having good governance by translating it to practical reality; and transform the administrative mechanism into service delivery mechanism and facilitator' (Good Governance (Management and Operation) Act 2008, Preamble).

The government of Nepal shall carry out administrative function at central, regional, zonal, district, and local level to maintain good governance within the country (Good Governance (Management and Operation) Act 2008, Section 3).It shall be the duty of the administrative authorities and concerned authorities to carry out administrative function of the country in speedy manner, with the objective of maintaining good governance and make available its outcomes to the people in time (Section 8).While carrying out administrative functions to maintain good governance in the country the concerned authority must carry out its functions on the basis of greater interest of nation and people; equity and inclusiveness; rule of law; guarantee of the human rights; transparency, objectivity, accountability and honesty; economic (financial) discipline, corruption-free, lean (smart) and people-oriented administration; impartiality and neutrality of administrative mechanism; access of people to administrative mechanism and its decision; decentralization and devolution of powers; and popular participation and optimum utilization of local resources (Section 6). This legal provision prescribes the administrative authorities to follow the norms and indicators of good governance while preforming its functions.

This Act talks about the transparency to be maintained while making decisions and states that, officials authorized to make decision must act in transparent way while making decision in any subject (Section 16). The official authorized to make decision must not decide the matter with conflict of interest by the fact that his/her direct benefit, concern or interest is involved in the matter, or the decision directly affects his/her successor or close relatives or provides direct benefit to the business or profession carried out by the member of the joint family of the decision maker (Section 18). This aim of this provision is to stop biasness and to ensure fairness and transparency in the decision. Similarly, the government of Nepal may make necessary consultation with stakeholder and civil society, if necessary, before the implementation of any matter of public concern (Section 20). Equally, "the government of Nepal may arrange for the provision of operating any project or programme with direct participation and ownership of the people" (Section 28). These provisions operationalize for maintaining participation and inclusiveness of all concerned stakeholders in the public issues.

Every governmental office (public office) responsible for delivering public service or involved in public relation should maintain citizen's charter in prescribed form and locate it in the visible place of the office (Section 25). This provision aims to display the detail statement of service offered by the concerned office and its nature and other procedures to be followed by the service user to obtain the service, estimated time for delivering the service and other matters prescribed in that office. Alike, every ministry, department and government agency and office should appoint any of its officials as a spokesperson, for the purpose of providing information to the stakeholders or general public about the activities and functions carried out by the ministry, department, and governmental agency or office. The objective of this provision is to give information of the public authorities to the general public. Commission for the Investigation of Abuse of Authority Act 1991, The Prevention of Corruption Act 2002, Public Procurement Act 2007 and Rules 2008, Right to Information 


\section{Good Governance in Nepal: Legal Provisions and Judicial Praxis}

Act 2007 and Rules 2009, Local Government Operation Act 2017 etc. are the relevant statutory measures to ensure good governance in Nepal.

A remarkable achievement of the apex court has been its use of the constitution and other laws as a tool to provide bedrock for good governance. When other branches of government and institutions else was crumbling, the court time and again came to the rescue of the nation, thereby being the course corrector (Rai, 2019). The Supreme Court of Nepal time and again take the landmark move and properly save the notion of good governance. In the case of Gopal Guragahin on behalf of Communication Corner Pvt. Ltd. vs. Office of the Prime Minister and Council of Ministers, Singhdurbar, Kathmandu (N.K.P., 2067, Vol.1, D.N. 8299, p.101) the Supreme Court held that, when the government preforms the governmental works by fully following transparency the citizens does not became victim of the impacts of red tapism, corruption, and delay. Right to be informed makes the government accountable towards the citizens. Transparent governmental works and citizens right to be informed always guides the government in right track.

In the case of Advocate Dhurba Prasad Chaulagain vs. Government of Nepal, Office of the Prime Minister and Council of MinistersSinghdurbar, Kathmandu et. al. (N.K.P., 2073, Vol. $3, D . N$. 9561, p.487), the norms and values of good governance can only be meaningfulness in the condition when the government staffs became sensitive and aware to deliver services to the service seekers. When any civil servant makes delay to provide service to the service seekers due to the cause including the use of mobile phone is the matter of departmental action. Nabaraj Silwal vs. Government of Nepal, Office of the Prime Minister and Council of Ministers, Singhdurbar, Kathmandu et.al., (N.K.P. 2073, Vol. 12, D.N. 9723, p. 2213), the subject of promotion must be relatively seen from the perspective of good governance, rule of law, accountable and limited government. Another similar case is Tulashi Prasad Neupane vs. Ministry of Energy Singhdurbar et. al. (N.K.P., 2074, Vol.5, D.N. 9806, p. 799)

While making decisions the principle of natural justice and due process of law must be followedby the court, administrative bodies and judicial entities. It helps to establish fair, just and impartial decision process. Modern civilized jurisprudence accepts human rights, independence of judiciary, separation of power, constitutionalism, rule of law, due process of law, procedure determined by the law, natural justice, reasonableness and prudent/justified action which are the principles of justice and aims to ensure fair dealing appropriate and impartial justice and good governance.

\section{Conclusion}

Good governance is normative standard for legitimate, accountable and effective ways of obtaining and using public power and resources in the pursuit of widely-accepted social goals. Good governance provides the guidelines and roadmap for the government to ensure stability and performance for their nation. The theme of good governance has significantly different roles depending on the political and cultural dynamics operating in each particular context. Openly speaking good governance has so many qualitative, scientific, rational, legitimate and democratic facets so that it is so popular and important to all. The internationally agreed norms of good governance is the foundation but states can adopt the native governance according to their culture, climate, local situation, life ways and need basing upon the principles of good governance. 


\section{Good Governance in Nepal: Legal Provisions and Judicial Praxis}

The existence, performance and measurement of democracy no longer stand differently from good governance. Good governance comprises democratic norms, values and principles so, both democracy and good governance share same facets and indicators. Rule of law, constitutionalism, transparency, participation, periodic election, legitimacy of government are the elements of good governance and democracy. It is practiced in democracy. Therefore, legal and constitutional provisions of good governance is indispensable in democracy. The domestic regime of Nepal, however, is enmeshed in a growing web of power woven by the domination of core (centrality of Kathmandu), Social (caste system), economic (feudalism), political (patron-client network), cultural (paternalism), psychological (sense of deprivation and powerlessness among under class) and gender (patriarchal from the society) and creating barriers from the people to realize their constitutional and human rights. So, that there are obstacles to maintain good governance in Nepal.

In Nepal there are several provisions of good governance in the constitution and other legislations. Likewise, the Supreme Court of Nepal time and again has also given the verdict in the issue of good governance. Having separate good governance legislation, constitutional provisions and other statutory provisions I don't feel hesitate to explore the reality that, there is no practice of good governance in Nepal. There are several issues of governance and good governance in Nepal but they are only limited in the black letters of law and in the verdicts of the court. Laws and verdicts of the court without the action and social effect is meaningless. Therefore, the existing governance system of Nepal needs to reform from the internationally accepted good governance principles, norms and standards including the appropriate and specific mechanism or agency for its practical implementation.

\section{References}

Addink, H. (2019). Good governance concept and context. $1^{\text {st }}$ Ed. Oxford University Press.

Ali, M. (2020). Governance and good governance: A conceptual perspective. https://pdfs.semanticscholar.org/2395/3c1185cb16f6c0ec5c17b50c579d4dc66796.pdf.

Ali, S.S. (2006). Kautilya and the concept of good governance, The Indian Journal of Political Science. 67(2),375-380.

Ansari, D.N. A. \& Singh, S. (2009 October and December). Good governance \& implementation in era of globalization. The Indian Journal of Political Science, 70(4), 30.1109-1120.

Aryal, P.N. (2011, July).The fundamental pillars of good governance: Transparency, accountability and participation. Journal of Academia. 1(1). Democratic Professors Association.

Barthwal, C.P. (2003, July-December). E-governance for good governance. The Indian Journal of Political Science. 64(3/4), 285-308.

Bhatta, B. (2076). Fundamentals of public administration. $10^{\text {th }}$ Ed. Sopan Monthly. 


\section{Good Governance in Nepal: Legal Provisions and Judicial Praxis}

Bhattari, N. (2013). Role of good governance in rural development, Swashasan (The Journal of Self-Governance \& Rural Development). 38, 28-38.

Dahal, G. (2011 October). Good governance: Theoretical perspectives. Pragyik Prabhaha. 2, 1-6.

Dahal, G. (2017 February). Democratic practice and good governance in Nepal, Journal of Political Science, XVII, 18-35.

Dahal, R.K. (1999). Prospects of good governance, Decentralization and good governance in Nepal. (G. B. Thapa ed.). $1^{\text {st }}$ Ed. Political Science Association of Nepal.

Dahl, R.A. (2005). On democracy. (Hariseekesh Upadhyay, translator of Nepali version). $1^{\text {st }}$ Ed. Creation Media Pvt. Ltd.

Dhaka, R.S. (2010).Right to information and good governance. $1^{\text {st }}$ Ed. Concept Publishing Company Pvt. Ltd.

Galligan, D.J. (2007). Law in modern society. $1^{\text {st }}$ Ed. Oxford University Press.

Gavriluta, A.F. \& Lotos, C.V.,(2018). Good governance \& the rule of law-major pillars of economic efficiency. Journal of Public Administration, Finance and Law.13. 123-133.

Gilbert, L. D.\& Allen, F., (2014). Democracy and good governance: The missing link in Nigeria. Mediterranean Journal of Social Sciences. https://www.researchgate.net/publication/269867317_Democracy_and_Good_Governance_ The_Missing_Link_in_Nigeria.

Good Governance (Management and Operation) Act (2064). http://www.lawcommission.gov.np/en/wp-content/uploads/2018/10/good-governancemanagement-and-operation-act-2064-2006.pdf.

Karpen, U.(2010). Good governance. European Journal of Law Reform. 12, 1-2, 16-31.

Khanal, B. (2018). Legal reform via reception of law. $1^{\text {st }}$ Ed. Bhrikuti Academic Publications.

Marinova, D. et. al. (2015).Deliberative democracy, global green information system \& spirituality, corruption. In R.N. Ghosh \& M.A.B. Siddique Eds. Good Governance and Economic Development Contemporary Analysis \& Case Studies. World Scientific Publishing Co. Pvt. Ltd.

Nanda, V.P. (2006January). The good governance concept revisited, The Annals of the American Academy of Political \& Social Science. 603.269-283.

Rahman, M.L. (2016). Rahman, M.L. (2016). Governance and good governance: A theoretical framework. Public Policy and Administration Research, 6, 40-50.

Rai, V. (2019). Rethinking good governance holding to account India's public institutions. Rupa Publications India Pvt. Ltd.

Rajbhandary, A.B. (2002). Introducing good governance in the public administration of Nepal. $1^{\text {st }}$ Ed. Centre for Studies on Democracy and Governance.

Journal of Political Science, Vol. 21, February 2021 


\section{Good Governance in Nepal: Legal Provisions and Judicial Praxis}

Rijal, Y.R. (2011). Government institutions \& local governance. $1^{\text {st }}$ Ed. Bhrikuti Academic Publications.

Riley, A.R. (2007, June). Good (native) governance. Columbia Law Review. 107(5).

Sangroula, Y. (2020). Concept of rule of law, human rights, good governance: Mutually reinforcing concepts. http://yubarajsangroula.com.np/assets/uploads/a629a-rule-of-law-andgood-governance.pdf.

The Constitution of Nepal (2072). Law Books Management Board.

Weiss, F., \& Steiner, S. (2006). Transparency as an element of good governance in the practice of the EU and the WTO: Overview and comparison. Fordham International Law Journal, 30, 1545. 